\title{
Biosensors for the Polyphenolic Content of Wine Determination
}

\author{
A.R.S. Júnior, M.J.F. Rebelo* \\ CCMM -Faculdade de Ciências da Universidade de Lisboa, Campo Grande, C 8 \\ 1749-016 Lisboa, Portugal
}

Received $29^{\text {th }}$ June 2007 ; accepted $4^{\text {th }}$ January 2008

\begin{abstract}
Laccase of different lots was used in the construction of biosensors for the determination of polyphenolic content of wine. Laccase was immobilized on modified polyethersulfone membranes and applied to a Universal Sensor electrode base system. Parameters of the biosensors thus prepared were studied with respect to caffeic acid as the model substrate. Sensitivity of $0.102 \mathrm{~mA} \times \mathrm{M}^{-1}$, RSD of $1.9 \%$, linear range of 5 to $35 \times 10^{-6} \mathrm{M}$, limit of detection of $8.8 \times 10^{-7} \mathrm{M}$, were determined.

Different values of the applied potential near $0 \mathrm{~V}$ were tested in order to choose that one which gives the best performance of the present biosensors. Citrate and tartarate buffer solutions at $\mathrm{pH} 3.5$ were used. Polyphenolic content of different red wines was determined at $+100 \mathrm{mV}$ vs. $\mathrm{Ag} / \mathrm{AgCl}$.
\end{abstract}

Keywords: polyphenolic, wine, biosensor, laccase, caffeic acid.

\section{Introduction}

The antioxidant ability of wine is a well known fact, nowadays. A moderate consumption of this beverage, mainly the red one, is associated to prevention of heart diseases. Polyphenols have been thought to play an important role in that effect [1].

Most laboratories determine the level of total phenol in wines by the FolinCiocalteu method, which is not an absolute measurement of the amount of phenolic materials but is based on their chemical reducing capacity relative to an equivalent reducing capacity of gallic acid in most situations [2].

However, caffeic acid is one of the phenols present in a high amount in wine and has been used as reference by some authors [3,4], when measuring the total content of polyphenols in wine.

Caffeic acid has been studied by several groups [3-7], who found that it was the preferred substrate among other polyphenols analyzed, being redox recycled between the adsorbed laccase (enzymatic oxidation reaction) and the electrode

\footnotetext{
* Corresponding author. E-mail address: mjrebelo@fc.ul.pt
} 
(electrochemical reduction reaction). However, apart from our group, none of these authors studied the system at the $\mathrm{pH}$ of importance for application in wine, which is 3.5. In fact, buffer at $\mathrm{pH} 8.5$ was studied in [3], and the groups in [6, 7] used buffers at $\mathrm{pH}$ 5.0, while those in [4] worked at $\mathrm{pH} 7.4$.

The aim of the present work was to study matrices at a $\mathrm{pH}$ value closer to the average $\mathrm{pH}$ of red wines (ca 3.5) than the previous authors did. In fact, in the present work, we have our system at $\mathrm{pH} 3.5$ either using $0.1 \mathrm{M}$ citrate buffer at $\mathrm{pH} 3.5$ or $0.033 \mathrm{M}$ tartarate buffer. The use of tartarate buffer was a further step to get model solutions closer to the wine composition. We also compared two different lots of laccases.

Laccase, like tyrosinase, is a multicopper oxidase which catalyses the fourelectron reduction of $\mathrm{O}_{2}$ directly to water (without the intermediate formation of hydrogen peroxide) with four sequential one-electron oxidations of substrate, e.g. phenolic compounds [8]. This redox reaction depends on the presence of four $\mathrm{Cu}$ atoms that are classified into three types of $\mathrm{Cu}$ sites, i.e., type 1 (T1), type 2 (T2), and type 3 (T3). The best studied members of this enzyme class are Rhus Vernicifera (Japanese lacquer tree) laccase (Lc), fungal Lc, ascorbate oxidase (AO), and human ceruloplasmin [9].

Structural data for laccase from Trametes versicolor [10] suggested a mechanism, by which laccases could tune their redox potential. T1 center lies embedded about $6.5 \AA$ below the surface of the enzyme. The copper occupies a depression of the enzyme surface and the authors found it was reasonable to assume that the T1 copper was the primary electron acceptor site. The coordination of the $\mathrm{T} 1$ copper in $\mathrm{TvL}$ and $\mathrm{CcL}$ is trigonal coplanar. Axial coordination has been considered to be one factor affecting the redox potential of copper enzymes.

The electrostatic surface potential distribution of TvL reveals a dominance of negative charges, which is in accordance with the acidic pI of about 3.5. From the crystal structure of an enzyme/substrate complex (unpublished observation), it was derived that the substrate bound in a small negatively charged cavity near the copper T1 site [10]. The negative charges located at this site may have functional significance, since they could stabilize the radical cation products that are formed during the catalytic cycle. The oxygen-reducing site at the T2/T3 cluster has access to solvent through two channels, which lead to the type-3 copper and to the type-2 copper sites, respectively.

Immobilization of an enzyme on derivatized polyether sulphone membranes as a step in the preparation of biosensors was done in our laboratory, for the first time, to our knowledge with tyrosinase [11]. This method of immobilization proved to be easy, rapid and effective and was also used in the present work.

\section{Experimental}

Materials and reagents

Laccases were 53739 and 38429 samples from Trametes versicolor, both from Fluka, EC (1.10.3.2). Caffeic acid: trans - 3,4- dihydroxycinnamic acid, was from Aldrich. PBS (Phosphate buffer saline) $\mathrm{pH}=7.4$, prepared with $\mathrm{NaCl}$ from 
Riedel-deHaën with purity greater than $99.8 \%, \mathrm{KCl}$ from Merck purity superior to $99.5 \%, \mathrm{Na}_{2} \mathrm{HPO}_{4}$ and $\mathrm{KH}_{2} \mathrm{PO}_{4}$, with purity superior to $99.9 \%$ and $99.7 \%$, respectively, both supplied by Sigma-Aldrich. Citrate buffer was prepared with citric acid monohydrate from Sigma. Tartarate buffer was prepared with tartaric acid from Riedel-deHaën, Analytical reagent. Concentrated $\mathrm{KOH}$ from RiedeldeHaën was added to citric and tartaric acid to make the $\mathrm{pH}$ equal to 3.5.

Caffeic acid solutions were freshly prepared at a concentration of $0.5 \times 10^{-3} \mathrm{~mol}$ $\mathrm{dm}^{-3}$ in citrate or tartarate buffer $\mathrm{pH} 3.5$, the day of the experiment.

Milli-Q A10, Millipore water was used to make up the solutions.

Polyethersulphone membranes (Ultrabind US450 $0.45 \mu \mathrm{m}$ ) were from Gelman.

\section{Equipment}

An amperometric biosensor detector from Universal Sensors (New Orleans, USA) was used to apply the potential and acquire the resultant current. The electrode system was also from Universal Sensors, the 4208 base electrode consisting of $\mathrm{Pt}$ - $\mathrm{Ag} / \mathrm{AgCl}$.

A Pharmacia Biotech recorder REC 102 was used to record the transients current vs. time.

\section{Methods}

Two kinds of biosensors were prepared with the two different samples of laccase. Laccase solution samples were immobilized on derivatized polyethersulphone membranes. The amount of enzyme solution used in each membrane was $30 \mu \mathrm{L}$ containing $0.2 \mathrm{mg}$ of enzyme. The membranes with the immobilized enzyme were applied to a US electrode system base and the biosensor thus prepared was studied. Caffeic acid was used as the substrate. The buffer solutions used in the caffeic acid solutions and in the wine assays were citrate and tartarate at $\mathrm{pH}$ 3.5. Citrate buffer was also used in the immobilization of the enzyme. However tartarate was not used for the immobilization of the enzyme. In fact there was no answer from the laccase containing biosensor when the enzyme was immobilized with tartarate buffer. Determination of the polyphenolic content of wine was done for different wines with the two biosensors formed (corresponding to each kind of laccase).

\section{Results and discussion}

Estimations of the polyphenolic content of wine done by us previously [5] required a solid phase extraction (SPE). Though that was not a very complicated step, it involved a pre-treatment of wine. In the present work we aimed to simplify the procedures. That is, a sample of wine was directly injected in the buffer where the biosensor was immersed. Some reports of attempts to doing the direct measurement of the total polyphenolic content of wine appeared recently in the literature. HRP was used as the recognition enzyme, at $\mathrm{pH} 6-9$ [12]. Tyrosinase, at pH 7.4 was used in [6] and laccase at $\mathrm{pH} 5.0$ in [4]. Tyrosinase and buffer at $\mathrm{pH} 8.5$ were used in [3] . 
The novelty of the present work was to prepare biosensors for the direct determination of polyphenols in wine with an easier method of immobilization, and more rapid than the other mentioned works. Moreover, we worked at a $\mathrm{pH}$ value of 3.5 , which is a $\mathrm{pH}$ value more similar to the values usually found in wine, than the values used by the other referred authors $[3,4,6,12]$.

Thus, we worked with citrate buffer and with tartarate buffer at $\mathrm{pH} 3.5$. At this $\mathrm{pH}$ value, the reactions of caffeic acid oxidation are as follows:

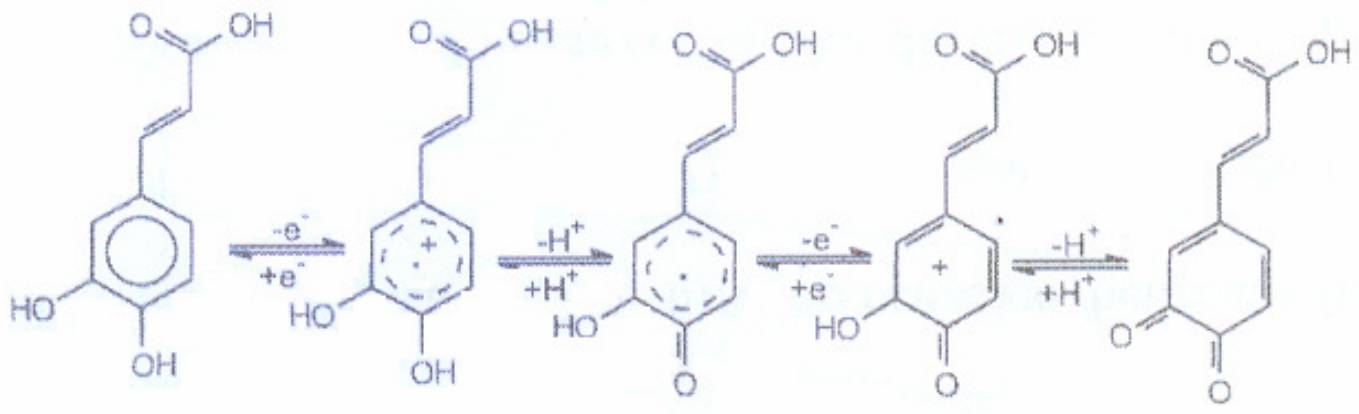

It is reckoned that the negative charges located at the site of laccase, where the substrate is oxidized, the so-called copper 1, may have functional significance, since they could stabilize the radical cation products that are formed during the catalytic cycle. This fact is another reason to support our choice of using a buffer of $\mathrm{pH} 3.5$ in the assays.

\section{Response of the biosensor to caffeic acid}

It was observed that the biosensors prepared with the different lots of laccase responded to caffeic acid in citrate buffer $\mathrm{pH} 3.5$ and in tartarate buffer $\mathrm{pH} 3.5$. The repeatability of the response is shown on Fig. 1. Values of $0.414 \mathrm{nA} \pm 0.008$, that is a RSD of $1.9 \%$ were obtained for a series of five assays. The lines represent intensity of current as a function of time, after injection of $50 \mu \mathrm{L}$ of 0.5 $\mathrm{mM}$ caffeic acid in citrate buffer $\mathrm{pH} 3.5$ into $5 \mathrm{~mL}$ of citrate buffer $\mathrm{pH} 3.5$, where the biosensor was dipped. The solution was stirred with a magnetic stirring bar. The base current was allowed to stabilize previously. The stabilization period was very quick on first use. However, there was a delay of a few minutes between runs, before the base line returned to a low value (0.00 to $0.03 \mathrm{nA})$ and the injection was done.

Reproducibility of the enzyme immobilization/biosensor performance was tested with two membranes where aliquots of $30 \mu \mathrm{L}$ of the same enzyme solution were immobilized. Reproducibility was of the same order of magnitude as repeatability.

The linearity of the response of the biosensor to caffeic acid is shown on figure 2 . The concentration range was $5.0-35 \times 10^{-6} \mathrm{~mol} \mathrm{dm}^{-3}$, the sensitivity being 0.102 $\mathrm{mA} \times \mathrm{M}^{-1}$. The limit of detection was $8.8 \times 10^{-7} \mathrm{M}$.

It should be stressed that a very low value of the background current was always sought. That fact was considered to be of relevance to get reliable responses 
when the sample was measured. Good reproducibility to caffeic acid response was also obtained with the other lot of laccase.

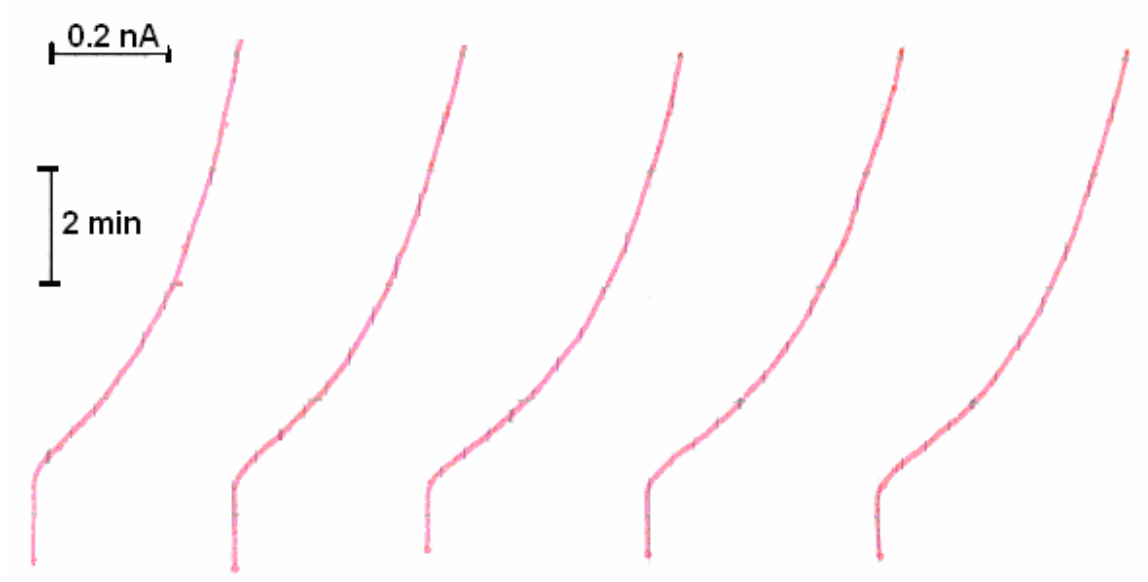

Figure 1. Repeatability of the biosensor to caffeic acid $5 \mu \mathrm{M}$ in citrate buffer $\mathrm{pH} 3.5$ [53739 Laccase] $\Delta \mathrm{I}=0.414 \mathrm{nA} \pm 0.008$. That is a $\mathrm{RSD}$ of $1.9 \%$.

\section{Response to wine}

Choice of the applied potential

The choice of the applied potential was done taking into account the main objective of the biosensor application, which was sensing total polyphenols in wine.

In order to do that, blank tests with the internal membrane on the electrode system were done, applying potentials already used by other authors. Thus, responses to wine were as shown in Table 1.

That is, there was a finite oxidation current of wine when potentials -100 and -50 $\mathrm{mV}$ (vs. $\mathrm{Ag} / \mathrm{AgCl}$ ) were applied to the electrodes base system with the internal membrane on. The assay consisted in adding a $200 \mu \mathrm{L}$ aliquot of wine to $5 \mathrm{~mL}$ of buffer, under magnetic stirring. There was also a slight oxidation at $+100 \mathrm{mV}$, but the value of the resultant current was negligible when compared to those obtained at the other mentioned potentials. Those results substantiate our previous choice of $E_{a p}=+100 \mathrm{mV}$, as the most appropriate for the measurements in wine with the present biosensor. In fact, at this potential, the response of the electrodes base system to wine was minimal and would not interfere with the response of the biosensor.

We, thus, measured the response of the biosensors, at the applied potential of $+100 \mathrm{mV}$ prepared with two lots of laccase.

Tests of the response to wine were dissimilar when the two lots of laccase were used, contrary to what had happened with caffeic acid. In fact, the biosensor prepared with 53739 laccase responded to wine, while the one containing 38429 laccase did not, as shown in Fig. 3. 


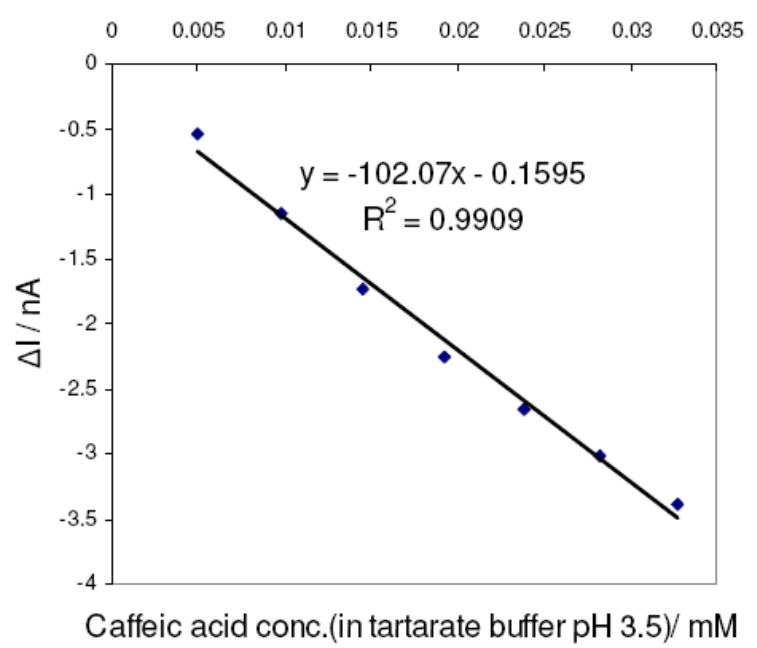

Figure 2. Variation of current with caffeic acid concentration.

Table 1. Current response of the electrode base system ( $\mathrm{Pt}$ wires vs. $\mathrm{Ag} / \mathrm{AgCl}$ ) to wine at potentials reported in the literature.

\begin{tabular}{l|ccc}
$\Delta \mathrm{I} / \mathrm{nA}$ & +0.22 & +0.07 & +0.01 \\
\hline $\mathrm{E}_{\mathrm{ap}} / \mathrm{mV}$ & -100 & -50 & +100
\end{tabular}
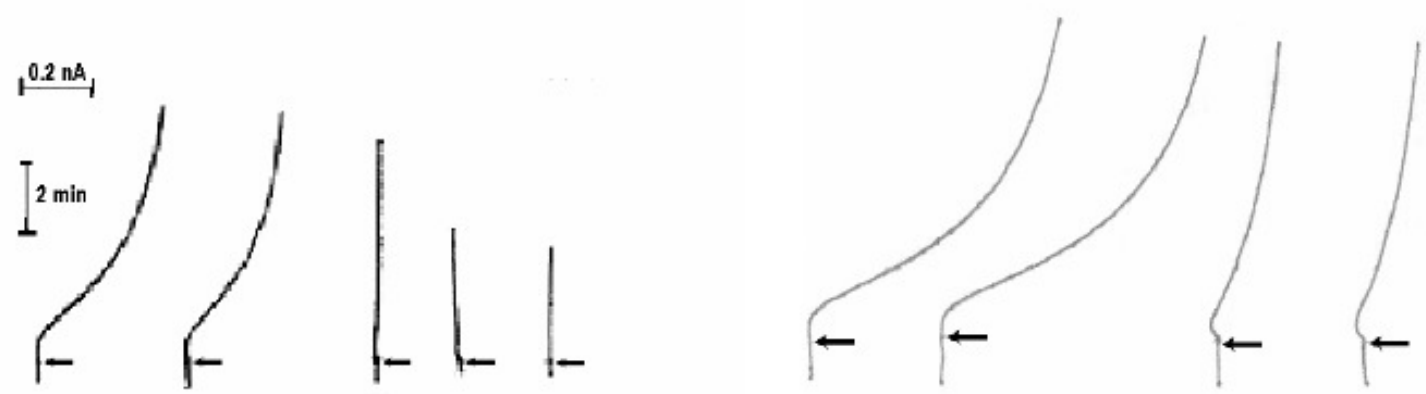

Figure 3. Response of the biosensor to caffeic acid and wine with the 38429 Laccase (a) and the 53739 one (b). The two first lines on each part of the figure, a and $\mathbf{b}$, correspond to the addition of $50 \mu \mathrm{L}$ of $0.5 \mathrm{mM}$ caffeic acid (in citrate buffer $\mathrm{pH} 3.5$ ) to $5 \mathrm{~mL}$ of the buffer; the other lines correspond to the addition of $200 \mu \mathrm{L}$ of wine samples of the same type, to $5 \mathrm{~mL}$ of the buffer. The arrows show where the additions of caffeic acid or wine were done.

Further evidence that the biosensor response to wine was related to the caffeic acid one was given by the decrease of the activity of the enzyme, on storage. In fact the decrease in the current response to caffeic acid after some days storage, 
dry at $4{ }^{\circ} \mathrm{C}$ was proportional to the decrease in the response to a definite sample of wine.

\section{Recovery}

Recovery studies were done with the biosensor for samples diluted 1:25. Values obtained ranged from $70 \%$ to $100 \%$ for the wine which had the largest amount of polyphenols.

\section{Storage}

The membranes were stored dry at $4{ }^{\circ} \mathrm{C}$ and used in the first 1 to 6 days. However, it was observed that the immobilized enzyme kept $71.4 \%$ of its activity after 24 days of storage, dry at $4{ }^{\circ} \mathrm{C}$. No measurements were made after that interval.

The activity towards caffeic acid was kept on storage in PBS (phosphate buffer saline), at room temperature for 6 days, but the performance of the enzyme seemed to have changed. That fact was probably due to the high level of chloride ion concentration in PBS [13].

\section{Response of the biosensor to different types of wines}

The biosensor prepared with the 53739 laccase was used to measure the polyphenolic content of several red wines. The results are presented on Table 2.

Table 2. Measurement of the polyphenolic content of wines, with respect to caffeic acid, done with our laccase biosensor.

\begin{tabular}{ccc|c} 
Red Wine & $\mathrm{pH}$ & $\begin{array}{c}\text { Buffer used for } \\
\text { dilution at } \mathrm{pH} 3.5\end{array}$ & $\begin{array}{c}\text { Caffeic acid } \\
\text { equivalent }\left(\mathrm{mgL}^{-1}\right)\end{array}$ \\
\hline Vale da Lágea & 3.44 & Citrate & 7.23 \\
Vale da Lágea & 3.44 & Tartarate & 7.23 \\
Dão (G.V.) & 3.63 & Tartarate & 6.53 \\
$\mathrm{HP}_{1}$ & 3.63 & Citrate & 5.66 \\
$\mathrm{HP}_{2}$ & 3.34 & tartarate & 17.2 \\
Auren & 3.35 & Tartarate & 7.44 \\
Vinha da Garça & 3.24 & Citrate & 2.20 \\
Porta da Ravessa & 3.14 & Tartarate & 3.78 \\
Arieno & 3.03 & Tartarate & 1.16
\end{tabular}

$\mathrm{HP}_{1}$ and $\mathrm{HP}_{2}$ were two home made wines. All the other wines were bought at a local shop.

There is a clear demarcation into two groups with high and low antioxidant content.

Wines having lower $\mathrm{pH}$ values also have the lowest caffeic acid equivalent contents. However, $\mathrm{pH}$ is not the only factor affecting the response of the 
biosensor. Studies to get a better understanding of the $\mathrm{pH}$ influence on the antioxidant behaviour of wine are in progress. It can be observed that the values of caffeic acid equivalent of the wines measured were of the same order of magnitude as those obtained by Pingarron et al. [4, 6]. The differences can be ascribed to the different conditions and to the different wines. However, taking into account all the differences, the similarity of results obtained point to a promising methodology to determine the total antioxidant content of wine.

\section{Conclusions}

A biosensor for the determination of the polyphenolic content of wine was obtained at $\mathrm{pH}$ 3.5. The method of immobilization was easy, rapid and robust and does not destroy the electrodes. Different wines were tested and the estimation of their total polyphenolic content was done with respect to caffeic acid solution in citrate and tartarate buffers at $\mathrm{pH}$ 3.5. Distinct contents could be obtained. The biosensor could be reused after having been used in wine, though longer times were required for those with the lowest polyphenolic content.

\section{References}

1. E.N. Frankel, J. Kanner, J.B. German, E. Parks, J.E. Kinsella, Lancet 341 (1993) 454-457.

2. E.N. Frankel, A.L. Waterhouse, P.L. Teissedre, J. Agric. Food Chem. 43 (1995) 890-894.

3. L. Campanella, A. Bonanni, E. Finotti, M. Tomassetti, Bios. Bioelectron. 19(7) (2004) 641-651.

4. M. Gamella, S. Campuzano, A.J. Reviejo, J.M. Pingarrón, J. Agric. Food Chem. 54 (2006) 7960-7967.

5. S.A.S.S. Gomes, J.M.F. Nogueira, M.J.F. Rebelo, Bios. Bioelectr. 20(6) (2004) 1211-1216.

6. V. Carralero Sanz, M.L. Mena, A. González-Cortés, P. Yáñez-Sedeño, J.M. Pingarrón, Anal. Chim. Acta 528 (2005) 1-8.

7. A. Jarosz-Wilkołazka, T. Ruzgas, L. Gorton, Enzyme and Microbial Technology 35 (2004) 238-241.

8. A.I. Yaropolov, A.N. Kharubiu, J. Emnéus, G. Marko-Varga, L. Gorton, Anal. Chim. Acta 308 (1995) 137-144.

9. L. Quintanar, A.E. Palmer, R. Hassett, S. Severance, D.J. Kosman, E.I. Solomon, J. Am. Chem. Soc. 123 (2001) 5507-5517.

10. K. Piontek, M. Antorini, T. Choinowski, J. Biol. Chem. 277 (40) (2002) 37663-37669.

11. P.P.V. Climent, M.L.M. Serralheiro, M.J.F. Rebelo, Pure Appl. Chem. 73(12) (2001) 1993-1999.

12. S. Imabayashi, Y.-T. Kong, M. Watanabe, Electroanalysis 13(5) (2001) 408412.

13. A. Lupu, D. Compagnone, G. Palleschi, Anal. Chim. Acta 513 (2004) 67-72.

14. F. Xu, Biochemistry 35 (1996) 7608-7614. 